was wrong to eonsider the size of passage withont further investigation as to changes of the size. Many eminent men loubted the reality of so-called cures of sterility, and he had no doubt that most eases were mere lucky eoincidences. He was not conrinced of the reality of any eures exeept in these cascs of combined dysmenorrhœa and sterility discussed in Dr. Godson's paper. One evidence in fivour of the reality of the cures was that all were done by snbstantially the same method - namely, dilatation of the cervix. Among the varions means of dilatation, lie held a well-known opinion in favour of that recommended in the paper just read.

Dr. Gonsos, in reply, said that his dilators were not curved any more than an ordinary uterine somul, and not so much as those used by the president. It seemed almost ecrtain that the patient npon whom Dr. Rogers had passed the dilators was suffering from congestive dysmenorrboa, and was not a fit subject for the treatment. It was most important that a proper diagnosis should be first arrived at, and that dilatition should be only practised where there was absence of congestion, otherwise there was great fiar of inflammatory mischicf ensuing. His paper treated only of spasmolic dysmenorrhoea assoriated with sterility, and therefore Dr. Priestley's remirks with respect to the treatment of young girls were outside the scope of the paper, but he entirely accorded with them.Lancet, Februan'y 11, 1882.

\title{
The Elastic Ligature in the Abdominal Extirpation of Uterine Fibroids.
}

One of the chief diffieulties in the extirpation by laparotomy of uterine fibroids has been to find some trustworthy method of securing the stump. The pedicle, being forned of muscular tissue, contracts, so that the clamp or ligature, a fow hours after it has been applied, will have become loaze. In at recent mumber of the Archio fiir Gyjäkologie a case is recorkerl in which the elastic ligature was successfully cmplnyed. It occurred in the chinique of l'rofessor Olshansen, and is reported by Dr. E. Scliwarz. The tumour, before operation, was supposed to be ovarian; its smootliness, the sense of pseudo-Anctuation which was f'elt over it, and the facts that it pressed down the uterus (which eould thus be palpated per vaginam apparently throughout its whole length) and that a ronncled elastic segment of the tumour could be felt behind the nterus, being the features which led to this error. An incision having been mate, and the tumour exposed, a trocar was thrust into it, but nothing escaped. The opening was then enlarged with the knife, and a (uantity of opapue, reddish-brown, thin fluid, and a mass of decolorized blood-clot as big as two fists (in all, weighing about thirty ponnds) was remover. The incision laving been prolonged upwards, and thus the bulk of the tunsour (which was found to grow from the upper and posterior part of the uterus) got outside of the abdomen, a piece of India-rubbcr drainage-tube was made fast round its pedicle to entrol hemorrhage. 'Then the tunour, the solid part of which weighed twelve pounds and a half, was exciserl, the pedicle being left of a funnel shape; the arteries visible were separitely taken up and ticrl, and the sides of the hollowed-out pericle were brought together by superficial and deep sutures. 'The Intia-rubber tubing was then talien off'; but blood welled up from the pedicle in such quantity as to call for some mode of stopping it which would not involve delay. A piece of India-rubber tubing about the thickness of a goose-ruill was therefore pnt twiee round the pedicle and tied. Between the two bands of tubing the stump was transfixed with a long needle, and it was then made fast to the abdominal walls, drainage-tubes were inserted, and antiseptic dressings applied. The part outside the ligature was nearly as big as the fist. The operation lasted one lour and three-quarters. In the evening the dressings were found soaked through, and on removing them, it was discovered that the 
necdle had broken, and the stump dropped into the abdominal eavity. The ends of the elastic ligatures were still outside. As there were no bad symptoms, it was not thonght necessary to interfere further. The drainage-tnbes were removed on the fourth day. The elastic ligature and the detached part of the pedicle eame away on the seventecnth day. The patient did well. Dr. Schwarz suggests some ingenious morlifications in the mode of applying the elastic ligature; and Professor Olshansen (who adds some comments) expresses himself as withont donbt that the elastic lierature is destined to play a large part in the treatment of eases similar to the one deseribed. We may add that a volume of Beiträge recently published to commemorate the jubilee of Professor Credé's occupation of his chair, contains a communication by Dr. Leopold, of Leipzig, bearing on the same subject. -Med. Iïmes and Gaz., Dee. 17, 1881.

\section{Diagnosis of Ovarian Thmours.}

Dr. A. Macdonatu mentions the following points as assistance in the differential diagnosis of oratian tumours :-

1. Iregnancy.-The possibility of pregnancy, the sigus and symptoms of pregnaney, and waiting if in doubt, place the diagnosis beyond possible mistake with a fair incasure of care.

2. Filmroid.-A large fibroid with solid walls, leading to general enlargement of the uterus, is easily cliagnosed. The increased length which the sound 'nters, the fact that the uterus moves with the sound, the peeuliar feel of the uterus, and the nearly constant menorrhatia, suffice to keep the dingnosis correet. It is quits common to hear a bruit in a ease of uterine fibroid; only in vascular sarcomata is such audible if the tumour is ovarian. But mol greater difficulty is experienced in eases of fibro-erstic tumours connected to the uterus with or with. out pedicle. In that case wi nust try to ascertain whether the tumom is eon. neeted or discounceted with the uterus. Then the cyst of a fibro-eystic tumour may be tapped, when we expect to find only a thin fhid of great density, with some blood-corpuseles, and possibly some non-striped muscular fibres. But in those cases it is often found that only an exploratory incision can determine the diagnosis with aecuracy.

3. Renal cysts begin below the fulse ribs and extend hownwards and forwards. They have a line of resonance between them and the liver due to the transverse colon, which is of valne as showing they are not of hepatie origin, and when aspirated they contain urea. Usually accompanying such there are urinary symptoms, but not always.

4. Ascites exlibits the charucters of fre motion of fluid in an imperfectly filkd eavity. Accordingly, when the pationt lies on her back the abdomen is flattened anteriorly, the flanks give a dull note, abd there is clearness round and above the umbilicus. With ehange of the patient's position the areas of resomance alter. Thus if the patient is turned on her left side, the right flank gives a clear note, and vice versa. In ease of tapping an ascites the thick gelatinous fluid characteristic of ovarian tnmour is never obtaincel.

5. Hydatid Cyst of the Liver.-In this ease the tumour grows from the liver, distending first the distance between the ensiform cartilige and the umbilicus, the reverse of an ovarian cyst. Again tapping and discovering acephalocysts in the fluid is convincing evilence of the true nature of the tumour.

6. Ilysterical abdominal distension, commonly known as spurious pregnancy, nced deceive no one, as the percussion is uniformly resonant, and the tumour disappears under chloroform._Edinburgh Med. Journ., Nov. 1881. 